\title{
A PARALEL BETWEEN THE INTERNATIONAL AUDIT STANDARDS REGARDING THE AUDIT REPORT WHICH IS APPLIED IN ROMANIA AND THE TECHNICAL AUDIT NORMS WHICH ARE APPLIED IN SPAIN
}

\author{
Ioana Iuliana Pop (Grigorescu) $)^{1}$
}

\begin{abstract}
At the beginning of this study I have determined the way in which have been taken the European Directive2006/43/CE concerning the International Standards of Audit in the national legislation in Romania and Spain. Then $i$ have realised a comparative analyses International Standards of Audit which refer to the audit Report, applicable in Romania and the Technical audit norm applicable in Spain, analyses where i have identified a series of differences.

At the end of research we found out that the identified differences are not significant and therefore it has been demonstrated the research hypothesis, according to which in Romania and Spain have been made important steps in harmonising the financial audit process, so that the juridical and professional frame in the two countries presents several similitude.
\end{abstract}

Key words: audit report, types of opinions, ISA, Technical Spanish norms, communication with the users, harmonising process

JEL Codes: M42

\section{Introduction}

"The financial communication unites the members of the society, including the organisations, into a dialogue of knowledge and efficient action in the economic activity domain.”[3]

The hypothesis from which this research goes is the fact that in Romania and Spain have been important steps in harmonising the financial audit process, so that the juridical and professional frame presents several similitudes, the differences being less significant.

In order to demonstrate this hypothesis, we propose to demonstrate the way in which have been adopted the regulations of the European Directives in the Romanian and Spanish legislation and realise a comparative analyses between the International Standards of Audit which refer to the Audit Report and the Technical Audit Norms in Spain .Also we will try to discover the differences between these norms and establish if they are significant or not.

The research brings novelty as a result of the fact that in present, in the Romanian specialty literature we have not identified any comparative study to analyse the differences between the International Standards of Audit used in our country and the audit norms applied in other European countries. This way we could evaluate the degree in which have been transposed in the national legislation the European Directives and the position regarding implementing the International Standards of Audit. Their adopting will ensure the level of transparency and comparison necessary at the international level concerning the usage of the audited accounting information.

In the Spanish specialty literature we have identified multiple preoccupations, because of the fact that the International Standards of Audit have not been adopted in this country. Names such as: Uyarra Encalado Esteban, Maria Antonia García Benau from University in Valencia, Herreros Escamilla Jorge and personalities from the Accounting and Audit Institute in Spain and from Professional Corporations in this country publish continuously normative comments referring the International Standards of Audit and the impact that adopting or non -adopting of these in Spain.

\footnotetext{
"1 Decembrie 1918" University of Alba Iulia, Romania, cotutoring Lleida University Spain, e-mail:
} ioanaiuliana69@yahoo.es 
The starting point of our analyses was represented by the fact that in Romania, though it is a country with a fewer tradition than Spain are applied the International Standards of Audit, and in Spain they still apply the Technical Norms elaborated in 1991. We have chosen as a study base those Standards and Norms which refer to the Audit Report because of its importance, representing the result and essence of the financial auditor's work.

\section{The research Methodology}

The research methodology is a qualitative one. Along the paper the data have been picked without quantifications or processing. The processing techniques of the used information have been: the critical evaluation of the documentation sources, systematisation, organising, comparing and analysing the obtained information. As work methods I have used the reading notes and the ideas plan.

At the beginning of the paper have been presented the hypotheses of the research and have been established the concrete objectives of work, and at the end of the study have been presented the obtained results and have been concluded if the hypotheses have been confirmed or not. To determine the way in which have been adopted the reglementations of the European Directives in the Romanian and Spanish legislation I have realised a documental research of the legal basis referring to the primary, secondary and third, such as:

- The legislation concerning the audit in Romania, Spain and E.U.;

- The national and international norms concerning the audit and accounting elaborated by IASB and AICPA (the International Audit Standards);

- The European Directives referring to the financial audit activity, especially the Directive 2006/43/EC;

- Electronic relevant data basis such as those published on the site of C.A.F.R., I.C.A.C, different Universities from the country and abroad, public Institutions from Romania, Spain and EU, different specialty magazines from the country and abroad;

- The specialty literature- from Romania, Spain and international literature- manuals, books, specialty articles, who contain neutral opinions, actual and quality ones for the researched theme.

By the help of the descriptive research I have realised the picking of the data from the above mentioned documents, their systematisation and then I have realised a critical description of the present situation. This way I have noticed that the situation of the two countries is differentRomania has adopted ISA, and Spain has remained at the stage of applying the Technical Norms emitted in 1991, with some modifications. Because of the fact that the Audit Report represents the result of the work of the financial auditor, I have compared the norms of the two countries which reglemented this activity.

The comparison has been used all along the research, but I haven't limited myself at a simple description of the present situation but I have tried to analyse and explain the found differences and resembling their causes and implications. At the end of the paper I have concluded that the made hypotheses have been demonstrated and I have also tried to propose some improvements of the reporting system.

\section{The legal basis}

In the member states of the European Community all the legal audits had to be made based on the International Standards of Audit. The Directive 2006/43/ CE by art. 26, imposes to the member states and therefore to "the legal auditors and audit firms to do legal audits according to the International Standards of Audit approved by the Commission". They add that "the member states can apply a National Standard of Audit as long as the Commission does not adopt an International Standards of Audit referring to the same problem" and the fact that the member states"can impose 
procedures or extra tasks....or can eliminate some parts, but only in the case they come as a result of an internal specific need".

In Romania the regulation is transposed exactly by the chapter V, art. 28 of O.U. 90/2008, where it is mentioned the fact that the International Standards of Audit will be taken as translated in their totality. Also it was emitted the Council CAFR nr. 152/23 from September 2009 by which the Chamber has adopted clarified which entered into vigour in December 15th 2009 ISA.

In Spain the situation is different. Before adopting the International Standards of Audit used to work very well the Technical Norms of Audit, elaborated by the Professional Corporations and approved by ICAC in 1991. Real Decretto nr. 1/2011 by which is approved the Revised text of the Financial Audit Law (TRLAC) art. 6(2) states that the audit norms, which had to be respected in Spain are the same to those comprised in TRLAC, in the Regulation that develops TRLAC, "in the International Standards of Audit adopted by the EU and the Technical Audit Norms( in Spain) for those non-ruled aspects of the international norms".

From our point of view, from this paragraph, it clearly results that from the moment of publishing the new Financial Audit Law, the International Audit Standards (ISA) have priority to the Technical Norms emitted by ICAC in Spain.

We notice the continuous presence of the "International Standards of Audit adopted by EU". The problem is the term "adopted". The ICAC official communication or the other organisms from Spain and specialty magazines interpret the ones in art. 6(2) from TRLAC:

- Directive 2006/43/CE introduces the International Standards of Audit which EU will "adopt";

- The National Technical Audit Norms remain available until the International Standards of Audit will be "adopted";

- The Directive establishes the possibility that the Technical Norms of Audit and those that will be emitted continuously to introduce additional audit tasks which will not apply some aspects from ISA which will contradict the national legislation.

For a detailed statement "ISA adopted by EU" we go to the Directive text 2006/43/CE, which states in the 13th paragraph that "The applying measures of applying the Standards in the Community which had to be adopted according to the Council's Decision 1999/468/CE from June 28th 1999, of establishing the executing competences given to the Commission".

Also the Directive 2006/43/CE states that "a technical committee or an audit group must assist the Commission in evaluating the ISA technical quality and also to involve the organs public surveillance system of the member states".

"To adopt by the Commission of ISA which should be applied at the Community level" this group will analyse the following conditions: "this has to be generally accepted at the international level and to have been elaborated with the full participation of the interested parts by an opened and transparent procedure" and moreover "to the general European interest".

Next, the art. 26 from the Directive 2006/43/CE states that: "the adopted International Standards of Audit are published in all the official languages of the Community in the Official Journal of the European".

If we study what the Directive 2006/43/CE states and what the Spanish publications say it results that ISA still have not been adopted at the community level, so they do not have a compulsory character for the member states. Still some states such as Romania have adopted them completely, and Spain tries to adjust the existing Technical Norms to the International Standards of Audit or at least not to come in conflict with these.

Art. 6 from TRLAC states that "the technical audit norms...will be elaborated, adapted and revised, so that to agree to International Standards of Audit adopted by EU". There can be added "additional tasks", or, there can be declared inapplicable those ISA parts which come into contradiction to the national legislation, respecting the legal procedures. The additional can be introduced by ICAC Resolution or emitting new Technical Norms. 
The position of the Spanish officials concerning the audit is favourable to ISA. The way of expressing this position in the Spanish legislation is still not clear enough, generating confusion among the financial auditors, which in present do not know exactly what have to applyInternational Standards of Audit or the Technical Norms in Spain.

While the new Law of the Financial Audit (TRLAC 2011) in article 6(2) states that the audit norms which had to be respected in Spain are those comprised in "The International Standards of Audit adopted by the EU and the Technical Norms in Spain for those aspects non reglemented by the international norms", still ICAC and the specialty literature from Spain considers that ISA haven't been "adopted" officially in EU and wait for this before applying them. That is why they continue to apply The Technical Audit Norms emitted in 1991.

Concretely, the actual situation in Spain is presented this way: ICAC has introduced in 2010 and 2011 the following modifications to the Technical Norms so that they do not enter in contradiction to ISA:

- The Resolution from October 7th 2010 on "The reasonable value";

- The Resolution from December 21st on "Figures and comparative financial situations";

- The Resolution from December 21st 2010 on "The audit report";

- The Resolution from June 27th 2011 on "The relation between auditors";

- The Resolution from October 26th 2011 regarding "The internal quality norm for auditors and audit firms".

This last Resolution is the only one which has effectively translated after ISQC1 (International Standard on Quality Control), and the rest of the resolutions reminded here have been "adapted" not "adopted". All the other technical norms emitted in Spain starting the year 1991 are still into vigour.

We notice therefore a significant difference in the way of applying the European Directives concerning the juridical and professional frame in the two countries.

Next we will realise analyse and effective comparison between the International Audit Standards with the Technical Spanish Norms regarding the Audit Report.

\section{The audit report}

The finality of the auditor's work is emitting a report, in which it should be expressed the opinion on the audited financial situations, so that any user of this information to be able to take decisions based on it, "The audit report presents the way in which the auditor communicates the shareholders and to the any other interested users the way in which is satisfied by the way the financial situations have been." [4].

In Romania, the International Audit Standards nr. 700 ,Expressing an opinion and reporting on the financial situations”, 705 „Modifications on the independent auditor opinion report” and ISA 706 "The observations paragraphs and the explicative paragraphs from the independent auditor report" establish the procedures and the fundamental principles and the way of applying the form and content of the independent auditor report. Most of the standards can be adapted in the case of different missions from the basic one. They are applied in Romania starting December 15th 2009.

ISA 800 „Special thoughts - the audit of the financial situations made according to the general frames with a special purpose" brings extra information on ISA 700, for the case in which the financial situations are made according to the general frame with a special purpose, ISA 805 „Special considerate - audits of the individual components of the financial situations of the specific elements, accounts or other aspects of the financial situations" referring to the audit to some components of the financial situations

In Spain, the Technical Audit Norm regarding "The Audit Report" approved by the Resolution from December 21st 2010 modifies the Technical Audit Norm from 1991 regarding the Audit and it is applicable for the financial situations starting January 1st 2011.It has all the components of the three Standards. 
This new change of the Technical Norm is due to the wish of adapting the Spanish Norms to the commentary and international ones. Therefore the Law 12/2010 from Spain has taken over the Directive 2006/43/CE. Regarding the Audit Report, the Law number 12 in article 2.1 states that the minimum content that had to be comprised in the Audit Report, to ensure the compatibility at the international level. So the ICAC (The Accounting and Audit Institute in Spain) considered that until the European Union will adopt ISA, it was necessary the modification of the Technical Norm regarding the Audit Report according to it.

Therefore the new Technical Norm in Spain in 2010 has in one law all the ISA 700, 705 and 706.

Table no. 1

\section{Norms that reglemented the aspects tied by the Audit Report in Romania and Spain}

\begin{tabular}{|l|l|}
\hline \multicolumn{1}{|c|}{ ROMANIA } & \multicolumn{2}{|c|}{ SPAIN } \\
\hline $\begin{array}{l}\text { ISA nr. 700 „Formulating an opinion and } \\
\text { reporting about the financial situations” }\end{array}$ & $\begin{array}{l}\text { Technical Audit Norm regarding the audit } \\
\text { report approved by the resolution from } \\
\text { December 21st which modifies and replaces } \\
\text { the Technical Audit Norm from 1991 } \\
\text { independent auditor report” }\end{array}$ \\
$\begin{array}{l}\text { ISA nr. 706 „observation paragraphs and } \\
\text { detailed paragraphs from the independent } \\
\text { auditor report” }\end{array}$ & \\
\hline
\end{tabular}

Source: self processing

From the analyses of the three International Audit Standards and of the Spanish Technical Norm, has come out the following Table, which comprises all the compulsory elements which should be contained by an Audit Report in Romania and Spain and all the types of opinions that the auditor can express within it.

The structure of the Audit Report

Table no. 2

\begin{tabular}{|c|c|}
\hline BASIC ELEMENTS & COMENTS \\
\hline TITLE & $\begin{array}{l}\text { N.T.A. } 2010 \text { from Spain in the paragraph 3.2.1. Says } \\
\text { that the title of the report must be, "A report about the } \\
\text { financial situations" to distinguish from any other kind of } \\
\text { report and ISA } 700 \text { in the paragraphs } 38 \text { and } 39 \text { states that } \\
\text { the title will be, "The independent auditor report" and as a } \\
\text { subtitle, "A report about other legal disposals and } \\
\text { reglementing ones". }\end{array}$ \\
\hline $\begin{array}{l}\text { IDENTIFYING THE } \\
\text { DESTINATORS }\end{array}$ & $\begin{array}{l}\text { In general it is about the firms' shareholders or the } \\
\text { persons who take care of the corporative governance [ISA } \\
700 \text {, paragraph. } 16 \text { and N.T.A]. }\end{array}$ \\
\hline $\begin{array}{l}\text { INTRODUCTORY PARAGRAPH } \\
\text { (Parrafo de alcance) }\end{array}$ & $\begin{array}{l}\text { Details: } \\
\text { - the audited entity; } \\
\text { - the financial situations have been audited; } \\
\text { - counts the audited financial documents; } \\
\text { - counts the significant accounting policy; } \\
\text { - specifies the audited period; } \\
\text { - responsibility of the management on the made financial } \\
\text { situations; } \\
\text { - the auditor responsibility to express an opinion. }\end{array}$ \\
\hline $\begin{array}{l}\text { MODIFYING PARAGRAPH } \\
\text { (Parrafo de salvedades) } \\
\text { It will have the title „The basis for the }\end{array}$ & $\begin{array}{l}\text { - explains the reason for the modified opinion; } \\
\text { - appears always between the introductory paragraph and the } \\
\text { opinion one; }\end{array}$ \\
\hline
\end{tabular}




\begin{tabular}{|c|c|}
\hline $\begin{array}{l}\text { reserve oppinion”, „Basis for the } \\
\text { imposibility of expressing an oppinion”. }\end{array}$ & $\begin{array}{l}\text { - modifies the title of the opinion paragraph into "Reserved } \\
\text { opinion" "Contrary opinion" or "The impossibility of } \\
\text { expressing an opinion" } \\
\text { - it is an Intermediate Paragraph and describes the limit of } \\
\text { the activity domain of the audit, non-respecting the } \\
\text { accounting principles that have been produced or the } \\
\text { omitted information. }\end{array}$ \\
\hline $\begin{array}{l}\text { THE OPINON PARAGRAPH } \\
\text { (Parrafo de opinion) }\end{array}$ & The opinion can be: \\
\hline $\begin{array}{l}\text { „The financial situations present, from } \\
\text { all the points of view all the significant } \\
\text { details..........according to [The general } \\
\text { frame of accounting] or „The financial } \\
\text { situations offer a corect image regarding } \\
\text { [The general frame of accounting]. } \\
\text { If it is not about the International } \\
\text { Financial Reporting Standard it will be } \\
\text { identified the juridical frame of origin of } \\
\text { the general frame. }\end{array}$ & FAVORABLE (favorable) \\
\hline $\begin{array}{l}\text { "With the exception of the decribed } \\
\text { aspects in the Basis paragraph for the } \\
\text { option with reserves the financial } \\
\text { situations offer a corect image". }\end{array}$ & $\begin{array}{l}\text { WITH RESERVES (con salvedades) } \\
\text { - because of non respecting the principles and } \\
\text { accounting criteria; } \\
\text { - because the significant and non-omnipresent lies. }\end{array}$ \\
\hline $\begin{array}{l}\text { "With the exception of the possible } \\
\text { effects of the described aspects in the } \\
\text { Basis Paragraph for the option with } \\
\text { reserves the financial situations offer a } \\
\text { corect image". }\end{array}$ & $\begin{array}{l}\text { WITH RESERVES (con salvedades) } \\
\text { - because of the incapacity of obtaining sufficient and } \\
\text { adequate evidence; } \\
\text { - because the significant and non-omnipresent lies; }\end{array}$ \\
\hline \multirow[t]{2}{*}{$\begin{array}{l}\text { "The financial situations do not } \\
\text { express the clear image of the estate, of } \\
\text { the financial situations, of the results and } \\
\text { cash flux". }\end{array}$} & $\begin{array}{l}\text { CONTRARY (desfavorable) } \\
\text { - because the significant and omnipresent lies; } \\
\text { - it will express all the reasons that have generated this } \\
\text { opinion. }\end{array}$ \\
\hline & $\begin{array}{l}\text { IMPOSIBILITY OF EXPRESING AN OPINION } \\
\text { (denegada) } \\
\text { - the audit cannot obtain adequate and sufficient } \\
\text { evidence; } \\
\text { - the effect of the non truth could be significant and } \\
\text { omnipresent. }\end{array}$ \\
\hline $\begin{array}{l}\text { OBSERVATION PARAGRAPH } \\
\text { (Parrafo de enfasis) } \\
\quad \text { It wil have the title "Observations". }\end{array}$ & $\begin{array}{l}\text { - can be asked by other ISA (ISA } 210,560,570,800 \text { ); } \\
\text { - refers to a presented aspect or described adequately in } \\
\text { the financial situations and which is basic for understanding } \\
\text { the financial situations by the users; } \\
\text { - appears after the opinion paragraph; } \\
\text { - it is used when the auditor observes an ambiguous } \\
\text { situation from which depend future actions which can have } \\
\text { effects on the financial situations; } \\
\text { - it will not be abused on its use. }\end{array}$ \\
\hline $\begin{array}{l}\text { EXPLICATIVE PARAGRAPH } \\
\text { (Parrafo de otras cuestiones) } \\
\text { It wil have the title "Other aspects". }\end{array}$ & $\begin{array}{l}\text { - can be asked by other ISA (ISA 560, 710, 720); } \\
\text { - refers to a presented aspect or described adequately in } \\
\text { the financial situations and which is basic for understanding } \\
\text { the financial situations by the users, of responsibility of the } \\
\text { auditor or the audit report; } \\
\text { - it is placed after the observation paragraph and the }\end{array}$ \\
\hline
\end{tabular}




\begin{tabular}{|l|l|}
\hline THE PARAGRAPH REGARDING & $\begin{array}{l}\text { opinion one or in any other part of the audit report so that } \\
\text { can be relevant for the respective section. }\end{array}$ \\
$\begin{array}{l}\text { THE MARKET REPORT } \\
\text { (Parrafo sobre el informe de gestion) }\end{array}$ & $\begin{array}{c}\text { Appears only in the technical audit norms in Spain; } \\
\text { - it is included when the financial situations are } \\
\text { accompanied by a market report; } \\
- \text { it says if the data from the report are according to the } \\
\text { data in the financial situations. }\end{array}$ \\
\hline $\begin{array}{l}\text { THE NAME, Auditor will sign personally or in the audit's firm } \\
\text { SIGNATURE OF THE AUDITOR }\end{array}$ & $\begin{array}{l}\text { name; } \\
- \text { it will specify the complete address; } \\
- \text { it will add the register number in CAFR or ICAC, sign } \\
\text { that it is authorised and recognised by that institution to } \\
\text { make audits. }\end{array}$ \\
\hline THE AUDIT REPORT DATUM & $\begin{array}{l}\text { The datum cannot be sooner than it have been obtained } \\
\text { sufficient and adequate audit data, the datum when have } \\
\text { been made the financial situations, or the datum when the } \\
\text { management has assumed the responsibility for the financial } \\
\text { situations. }\end{array}$ \\
\hline
\end{tabular}

Source: self processing

All the basic elements are met in both countries, with the exception of the Paragraph regarding the Market Report that is to be met only in the Spanish Technical Norms.

The differences between the International Standards of Audit which are applied in Romania and the Technical Audit Norms in Spain regarding the Audit Report

As we compared and analysed the legal aspects connected by the audit Report comprised by the Audit Standards which are applied in Romania and the Technical Norms in Spain we have noticed several differences which will be synthesised in the following table:

Table no. 3

The differences between the International Standards of Audit and the Technical Norms in Spain regarding the Audit Report

\begin{tabular}{|c|c|}
\hline ROMANIA & SPAIN \\
\hline $\begin{array}{l}\text { ISA nr. } 700 \text { "Formulating an opinion and } \\
\text { reporting regarding the financial situations" }\end{array}$ & \multirow{3}{*}{$\begin{array}{c}\text { The Technical Audit Norm regarding } \\
\text { the Report approved by the Resolution } \\
\text { from December } 21 \text { st } 2010 \text { which } \\
\text { modifies and replaces The Technical } \\
\text { Audit Norm from } 1991\end{array}$} \\
\hline $\begin{array}{l}\text { ISA nr. } 705 \text { "Modifications of the report's } \\
\text { opinion of the independent auditor" }\end{array}$ & \\
\hline $\begin{array}{l}\text { ISA nr. } 706 \text { "The observation paragraphs and } \\
\text { the explicative paragraphs from the } \\
\text { independent auditor report " }\end{array}$ & \\
\hline $\begin{array}{l}\text { The entering into vigour datum December } \\
\text { 15th } 2009\end{array}$ & $\begin{array}{l}\text { The entering into vigour datum: January } \\
\text { 1st } 2011\end{array}$ \\
\hline ISA are more detailed & $\begin{array}{l}\text { N.T.A. } 2010 \text { has in a very comprised } \\
\text { form the tasks of the three ISA }\end{array}$ \\
\hline $\begin{array}{l}\text { The most tasks of these standards can be } \\
\text { adapted in the case of different missions from the } \\
\text { basic one }\end{array}$ & $\begin{array}{l}\text { N.T.A. } 2010 \text { refers to the basic mission, } \\
\text { statutory audit- a complete set of financial } \\
\text { situations. }\end{array}$ \\
\hline $\begin{array}{l}\text { ISA nr. } 700 \text { Formulating an opinion and } \\
\text { reporting regarding the financial situations }\end{array}$ & $\begin{array}{l}\text { The Technical Audit Norm regarding } \\
\text { "The Audit Report"6 }\end{array}$ \\
\hline
\end{tabular}


ISA 700 defines the notions of:

- general purpose frame which is divided in general with clear presentation and conformity general frame;

- financial situations

- International Standards of financial Reporting;

ISA 700in the paragraphs $38-39$ give as a title this one: „the report of the independent auditor" which will also have a subtitle, in the case it is about a Report regarding legal disposals and of reglementing

ISA makes several comments on the introductory paragraph content:

- the fact that the financial situations have been audited;

- they count all the documents comprised by the financial situations, the accounting policy, and the audited period;

- the selected procedures depend on the auditor's thinking and evaluating the risks procedures;

- analysing the internal control it does not have as a purpose expressing the works efficacy;

- evaluating the adequate degree of the used accounting politics realised by the firm management of the audited firm;

- the auditor thinks that the obtained evidence are sufficient and adequate to formulate an opinion;

- if in this paragraph the auditor does not say about procedures he could not apply, it means that it realised all the evidence and procedures asked by ISA .

ISA 700 specifies that in case the auditor is imposed by a law to add another specific statement, he can refer to ISA only if in the audit report will include the basic specified elements.

ISA 705, ,modifications of the opinion of the independent auditor report

ISA 705 defines the term of modified opinion and "omnipresent".

ISA 705 in paragraph 28 states that in case the auditor has the intention to modify the option from the audit report he has to say this thing to the designed persons with the corporative governance, including the reasons that lead to this opinion
N.T.A. 2010 does not contain these things.

N.T.A. 2010 in Spain in the paragraph 3.2.1.says that the title of the report must be „Report regarding the financial situations", to be different from any other type of report.

N.T.A. 2010does not contain these comments
N.T.A. 2010 does not refer to this aspect

The Technical Norm regarding "The audit report"

N.T. 2010 does not define the term of "modified opinion" and "omnipresent" but names several types of modified opinions.

The Spanish Technical Norm does not states this aspect. 


\begin{tabular}{|c|c|}
\hline ISA 705 does not states this aspect & $\begin{array}{l}\text { formulates an opinion with reserves or } \\
\text { contrary, cannot express a partial opinion. } \\
\text { In exceptionally cases in the case of initial } \\
\text { audits, when the auditor is not convinced } \\
\text { about the reality of the initial audits, he will } \\
\text { have to state an opinion. In the same report } \\
\text { can be stated a distinct opinion the rest of } \\
\text { the papers containing the financial } \\
\text { situations. This way the opinion will not } \\
\text { refer to the complete financial situation but } \\
\text { specific to certain documents }\end{array}$ \\
\hline $\begin{array}{c}\text { ISA } 706, \text {,the observation paragraphs and the } \\
\text { explicit paragraphs from the independent } \\
\text { auditor report }\end{array}$ & $\begin{array}{l}\text { The Technical norm regarding "The } \\
\text { audit report" }\end{array}$ \\
\hline ISA 706 defines the Observations Paragraph. & $\begin{array}{l}\text { N.T. from } 2010 \text { does not define the } \\
\text { Observation Paragraph. }\end{array}$ \\
\hline $\begin{array}{l}\text { ISA } 706 \text { names other ISA which contain } \\
\text { tasks referring the Observation Paragraph. These } \\
\text { are: ISA } 210,660,570 \text { and ISA } 800 .\end{array}$ & $\begin{array}{l}\text { N.T. from } 2010 \text { does not contain tasks } \\
\text { referring other Standards. }\end{array}$ \\
\hline $\begin{array}{l}\text { ISA } 706 \text { in the paragraphs } 9 \text { and } \mathrm{A} 5-\mathrm{A} 7 \text { it } \\
\text { is much richer in explanations and specifies that } \\
\text { the Explicative Paragraph will be named "Other } \\
\text { aspects" and will appear after the Observation } \\
\text { Paragraph and the Opinion one or in any other } \\
\text { part of the auditor report if the content of the } \\
\text { explicative paragraph is relevant to that section. }\end{array}$ & $\begin{array}{l}\text { The Technical Norm does not allow } \\
\text { placing the Explicative Paragraph in any } \\
\text { part of the audit report but only after the } \\
\text { Observations and Opinions Paragraphs. }\end{array}$ \\
\hline $\begin{array}{l}\text { ISA } 706 \text { in the annexes no. } 2 \text { contained tasks } \\
\text { of other ISA referring the Explicative Paragraph. } \\
\text { These are: ISA 560, paragraph } 12 . \mathrm{b} \text { and } 16 \text {, } \\
\text { ISA } 710 \text { paragraphs } 13-14,16-17 \text { and } 19 \text { and } \\
\text { ISA } 720 \text { paragraph } 10 \mathrm{a} \text {. }\end{array}$ & $\begin{array}{l}\text { N.T. from } 2010 \text { does not contain tasks } \\
\text { referring to other Standards. }\end{array}$ \\
\hline $\begin{array}{l}\text { The persons involved with the governance } \\
\text { will be notified if the auditor wants to introduce } \\
\text { an explicative paragraph and will offer the } \\
\text { necessary clarifications. }\end{array}$ & $\begin{array}{l}\text { The Technical Audit Norm does not } \\
\text { contain these aspects . }\end{array}$ \\
\hline
\end{tabular}

Source: self processing

Firstly i would like to state that in the case of "adapting" during 2010 of the old technical norm in Spain regarding the Audit Report at the International Audit Standards nr. 700, 705706 we notice that these have been put into a single technical norm approved by the Resolution from December 21st 2010 on "The Audit Report". Moreover the International Audit Standards refer to different basic missions to the basic one, while the Technical Norm in Spain refers to audit missions only.

As a general difference we notice that the International Audit Standards give more definitions, offer more conceptual clarifications and refer to actual terms - general purpose frame, financial situations, International Audit Standards, omnipresent, modified opinion, observation paragraph, etc. The technical Norm from Spain regarding the Audit Report is applied since 1993, but the economic environment has changed very much in the meantime. Adopting ISA at the Spain level would ensure the existence of a conceptual common basis regarding the audit missions. 
We also notice several statements referring the content of the Introductory Paragraph or to the fact that in case the auditor has the intention to modify the option from the audit report, or has the intention of introducing an Explicative Paragraph, he has to communicate this thing including the reasons that lead to this opinion, to the persons responsible with the corporative governance.

The International Standards give more flexibility to the elements comprised in the Audit Report. For example the Explanation Paragraph will appear according to ISA 706 after the observation and opinion one or in any other part of the auditor report if the content of the explanation paragraph is relevant to the respective section. In exchange the Technical Norms do not give this possibility and allow placing this Paragraph only after the Observation and Opinion Paragraph.

Moreover for what foresees the international standards of audit, the technical norm from 2010 refers to the case in which can be pronounced a partial opinion. Exceptionally, in the case of the initial audits, will have to be emitted an opinion with reserves or a contrary one. If it is possible in the same report it will be emitted different from the reserved or contrary one, for the rest of the documents that compose the financial situations. This way the opinion will not refer to the financial situations on the whole, but specific to certain documents.

\section{Conclusions}

Along the research I have noticed the existence of some differences between the International Audit Standards referring to the Audit Report and applied in Romania and the Technical Audit Norm regarding the Audit Report applied in Spain.

We consider that they are minor and do not have a significant effect, as the structure and content of the audit report are almost identical, and the types of opinions which can be expressed are the same so that any "rational user" no matter the country, could take decisions based on it. We consider that the differences are more formal than fond ones, so that the comparability of the audit report in the two countries is assured.

In the conditions of the actual international economic crises I think that it is good to introduce some uniform work mechanisms to obtain accounting financial information comparable and transparent. Important international organisms (IOSCO, INTOSAI, OECD, ONU) defends and sustains the idea that using the International Audit Standards must be generalised. In this respect, IFAC has revised and actualised ISA, representing in this moment the most important reference at the world level concerning the principles and conditions that have to follow the auditors.

As a result of analysing the actual situation in the two countries, in Spain's case I make the recommendation that ICAC to accelerate the harmonising process of the Technical Norms with the International Standards of Audit, or to pass to adopting them completely to raise uniformity, transparency, and credibility of the audited accounting information, which is needed by the society and economic environment. The European Commission underlines the fact that the unjustified delay of approving the International Audit Standards (ISA) could have a bad effect on reglementing frame, enriching the fragmentation, which comes against the general objective of the Directive.

Though Romania has entered in the member states in EU twenty years later than Spain, we could underline the more alert factor of adapting of the Financial Auditors Chamber in Romania to the European Directives and International Standards, than the Accounting and Audit Institute in Spain. The adapting process is not an easy one, but this rhythm comes probably from Romania's wish of integrating, of progress.

The hypothesis from which this research has started is that in Romania and Spain have been made important steps in harmonising the financial audit process so that the juridical and professional frame of the two countries presents several similitudes, the differences being less significant.

To demonstrate this hypothesis we have established the first objective of the research the way in which the European directives were adopted in the Romanian and Spanish legislation. The 
result of the research was the discovery of a significant difference in the way of applying the European directives in what the juridical and professional frame is concerned in the two countries.

In Romania was realised an ADOPTING of ISA, a complete taking over in the way of the full translation of it, while in Spain it was realised a partial ADAPTING of the Technical Norms at ISA. From here comes a series of differences, of particularities, in the two countries, which have been discovered because of establishing the second objective of the research which refers to realising comparative analyses between the International Standards of Audit which refer to the audit Report which applies in Romania and the Technical Audit Norms applied in Spain.

The discovered differences do not have a significant character, as the main Technical Norms in Spain have been adapted so that not to enter in the direct contradiction with the International Standards of Audit. The problem is still that they are few, do not contain ISA details and do not the conceptual clarifications which ISA offers. There are also elements that ISA has and completely miss from the Spanish Technical Norms.

Even if there are these differences between Romania and Spain regarding the way of understanding and applying the European Directives, we consider that it is important the orientation of the two countries towards the same objective, the acceptance of the International Standards of Audit as an international model which stays at the basis of uniformity the financial audit process. Anyway we consider that their taking over in their totality at the level of Spain is just a matter of time.

Organisation and the way of realising the auditors work offer the basis to obtaining the wanted results after the audit mission. The results refer to offering the users a high trusting degree in the audited financial situations. In the conditions of a global economy it is necessary organising and realising of an audit mission which can be obtained by adopting the International Standards of Audit, which bring conceptual clarifications and explain step by step the way of realising an audit mission. Their applying ensures the level of quality necessary to answer the actual information needs.

\section{References}

1. Dobroțeanu L., Dobroțeanu C., 2002. Audit concepts and practices - national and international approach, Economic Publishing House, Bucharest

2. Domnişoru S., Briciu S., Popa I.E., Bunget O.C., 2010. Statutory Audit vs. financial communication. Why and How, Financial Audit Magazine, no. 7, pp. 3-13

3. Herreros Escamilla J., Normas Internacionales de auditoría: principales impactos del "Proyecto Clarity", Revista Partida Doble nr. 224/2010, page, pp. 18-27

3. International Accountants Federation, 2009. International Audit Standards and quality Control Manual; Financial Audit, Irecson Publishing House, Bucharest

4. International Accountants Federation, 2008. International Regulations of audit, assurance and ethics, Irecson publishing House, Bucharest

5. Instituto de Cesores Jurados de Espana, 2011. Comentarios normativos sobre las Normas Tecnicas de Auditoria, Auditores Magazine no. 14, pp. 58-65

6. Neamțu H., Roman A.G., Țurlea E., 2012. Financial audit-assurance missions and side services, Economic Publishing House, Bucharest

7. Tabără N., Briciu S., 2012. Actualities and perspectives in accounting and market control, Tipo Moldova Publishing House, Iaşi

8. Toma M., 2009. Initiation in the financial situations audit of an entity, 3rd edition, revised and enlarged, CECCAR Publishing House, Bucharest

9. Directive nr. 2006/43/CE of the European Parliament from May 17th 2006 which refers to the legal audit of the financial situations and annual consolidated accounts, which modify the Directives IV-a and VII and erases Directive 84/253/CEE, published in the Official Journal of the European Union nr. 157/9 June 2006 
10. The Council Decision nr.1999/468/CE from June 28th 1999 of establishing the norms regarding the executing competences of the Commission, published in the Official Journal of the European Union. nr. 184 from July 17th1999

11. Law nr. 12 of the financial audit in Spain, from June 30th 2010, which modifies the law nr. 19/1988, approved by Real Decretory Legislative nr. 1564/1989 and published in BOE nr. 159 from July1st 2010, and which recently has been replaced with TRLAC - the revised text of the Financial audit Law, approved by the Real Decretory nr.1 from July 1 st 2011

12. Law nr. 26 from 2010, which modifies and completes O.U.G. nr. 75/1999, regarding the financial audit activity in Romania, published in the Official Monitor of Romania Part I, nr. 145 from March 5th 2010

13. Technical Audit Norms, "Normas Tecnicas de auditoria" in Spain, emitted by Icac, starting 1991 with the modifications and adds that followed, including the ones from 2010 and 2011, www.rea.es

14. O.U.G. 75/1999 regarding the financial audit activity, republished according to art. III from the Govern's Ordinance nr. 67/2002, published in the Official Monitor of Romania Part I, nr. 649 from August 31st 2002, the texts being given new numbers. The Emergency Ordinance nr. 75/1999, published in the Official Monitor of Romania Part I, nr. 256 from June 4th 1999 was approved with modifications and completed by the Law nr.133/2002, published in the Official Monitor of Romania, part I, nr. 230 from April 5th 2002 and was approved with modifications and completed by the Govern Ordinance nr. 67/2002 approved with modifications and completed by the Law nr. 12/2003 published in the Official Monitor of Romania Part I, nr. 38 from January 23rd 2003.

15. Emergency Ordinance nr. 90 from June 24th 2008 regarding the statutory audit of the annual financial situations and of the annual consolidated financial situations published in the Official Monitor of Romania nr. 481 from June 30th 2008

16. The revised text of the Financial Audit Law (TRLAC), approved by Real Decretory nr. 1/2011, published in B.O.E. no. 157 from July 2nd 2011

17. The applying regulation of TRLAC, approved by Real Decretory Legislative nr. 1, from July 2011, published in BOE nr. 266 from November 4th 2011 